\title{
Le intenzioni di progetto. Disegno, rilievo e documentazione di luoghi della rappresentazione
}

\author{
Fabiana Raco
}

Abstract

Architettura e messaggio. "Se consideriamo che la nozione di messaggio implica quella di linguaggio, nel nostro caso il progetto comunica attraverso un linguaggio" [De Simone 1980]. Come linguaggio l'architettura richiede la facoltà di selezionare e porre in relazione informazioni, pensieri, sentimenti, e di definire le tipologie di strumenti e forme, le tecniche, il significante, al fine di trasferire con efficacia le intenzioni, significato, del progetto. II linguaggio implica criteri, metodi e pluralità di finalità; tecnica, scientifica, poetica, letteraria. Le modalità di rappresentazione del progetto, attraverso i mezzi di cui esso dispone in un determinato periodo storico, divengono pertanto oggetto dell'indagine, così come il rilievo, la diagnostica e le possibilità di visualizzazione avanzati strumenti per rintracciare, e mantenere memoria, dei significati sottesi al progetto di architettura. Architettura e messaggio-linguaggio nel passaggio dal saper fare artigianale all'industriale, quale si verifica, ad esempio, nel $X X$ secolo a cavallo tra le due guerre, è un filone di ricerca che vede nel caso studio della Cittadella della Cultura di Ferrara un interessante momento di riflessione sul rapporto tra rappresentazione e progetto, nel contesto di un centro storico minore.

Parole chiave

progetto, linguaggio, disegno, rilievo, rappresentazione.

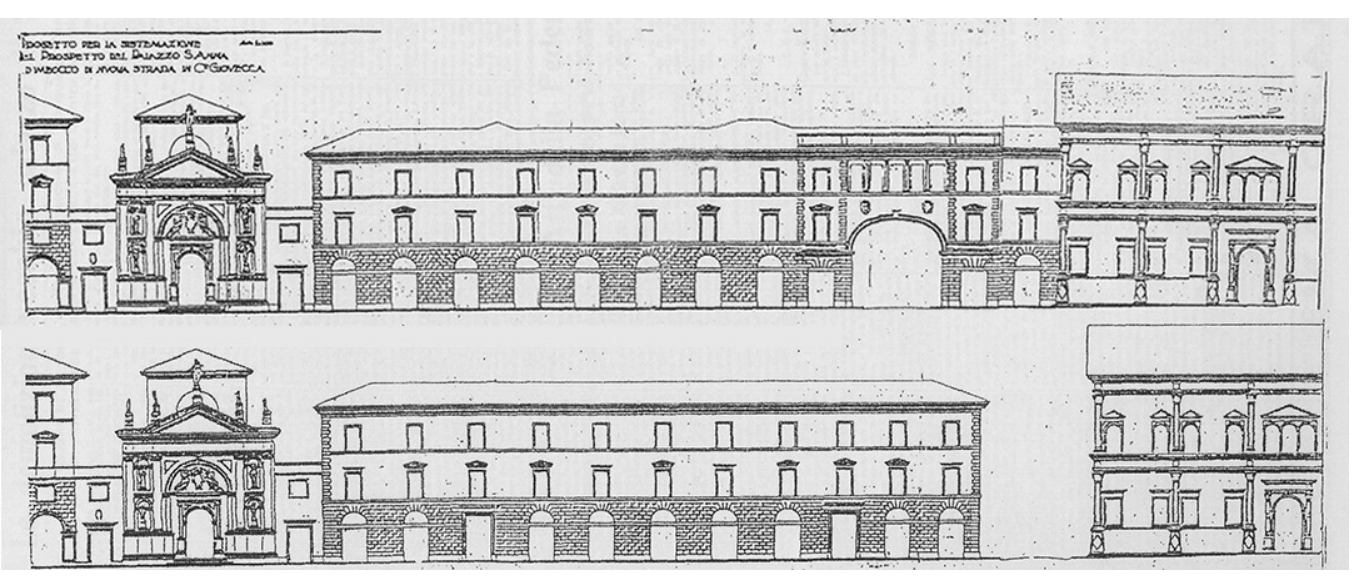


"Mi piacciono in architettura le cose d'insieme. [...] Ecco in poche parole quello che voglio dire: i nostri cenacoli razionalisti negano, in verità solo teoricamente, a funzione fondamentale, umana, della bellezza, cioè l'azione benefica e tonificante che l'armonia ha sopra di noi"

[Le Corbusier 194I].

II progetto dell'ingegnere Carlo Savonuzzi per la nuova Cittadella della Cultura della città di Ferrara, realizzato tra il 1931 e il 1939, si inserisce all'interno di quell'area culturale del Movimento Moderno, che pur aprendo una stagione di critica rispetto a precedenti metodi di rappresentazione del progetto, e non solo, recupera, in analogia ad alcuni maestri quali Khan e Alto, il ruolo centrale di alcune espressioni figurative, quali la prospettiva ad esempio, per descrivere il rapporto tra contesto, urbano innanzitutto, e osservatore [De Simone 1980]. Nel progetto di architettura, così come del design del prodotto industriale, tanto il mezzo della rappresentazione, il significante [De Saussure 2009], quanto il fine, il significato [De Saussure 2009], possono costituire, in virtù dell'azione ricorsiva che li lega [Gaiani 20 I 0], oggetto di osservazione al fine di individuare l'evoluzione del rapporto tra autonomia dell'atto rappresentativo e opera realizzata.

La relazione tra l'osservatore, il fruitore, e l'architettura guida allo stesso modo il progetto tecnologico e di dettaglio del nuovo quartiere, che si fonda, nel caso specifico del progetto in esame, sull'applicazione della 'moderna scienza acustica' e sull'uso sperimentale di materiali innovativi, quali il cemento amianto, per il progetto della sala concerti del nuovo Liceo Musicale Girolamo Frescobaldi. Lo studio del rapporto tra progetto e messaggio-linguaggio indaga, attraverso l'analisi dei disegni di progetto prima ancora che dell'opera realizzata, la relazione tra l'idea, la struttura, la forma e le scelte tecnologiche e dei materiali, nel contesto della tipologia specifica di un luogo della rappresentazione, quale appunto la sala concerti e non solo. II mostrare alla vista una scena, rappresentare, è tema fondante del progetto di Carlo Savonuzzi. II rapporto tra spazio scenico e gli spazi dell'osservatore, la platea e la galleria, è definito tanto da esigenze funzionali, quanto di composizione architettonica e di rapporto con le preesistenze. Le generatrici dell'impianto urbano perseguono i medesimi principi compositivi, mentre la giustapposizione di strutture antiche moderne definisce i fronti principali, permettendo al contempo la lettura dell'antico e l'unitarietà della scena urbana.

Un intervento a scala urbana, architettonica e di dettaglio al tempo stesso, che si esprime nel progetto di materiali e tecnologie, sia contemporanei che tradizionali, così come nello

Fig. I.A. Bolzoni, Pianta e alzato della città di

Ferrara, 1747 (dettaglio)

Contini, Ciro, Piano

Regolatore Generale

e d'Ampliamento della città e dei sobborghi

di Ferrara, 1913-26,

Archivio Storico

Comunale di Ferrara,

Repertorio XX secolo,

Sezione Cartografica,

Piani Generali, cart. IH

Savonuzzi, Carlo, Schizzo

per la trasformazione

dell'area dell'ex Ospedale

Sant'Anna, progetto

Sant'Anna, progetto

realizzato, 1932, Archivio

di Architel, Dipartimento

di Architettura, Universita di Ferrara.
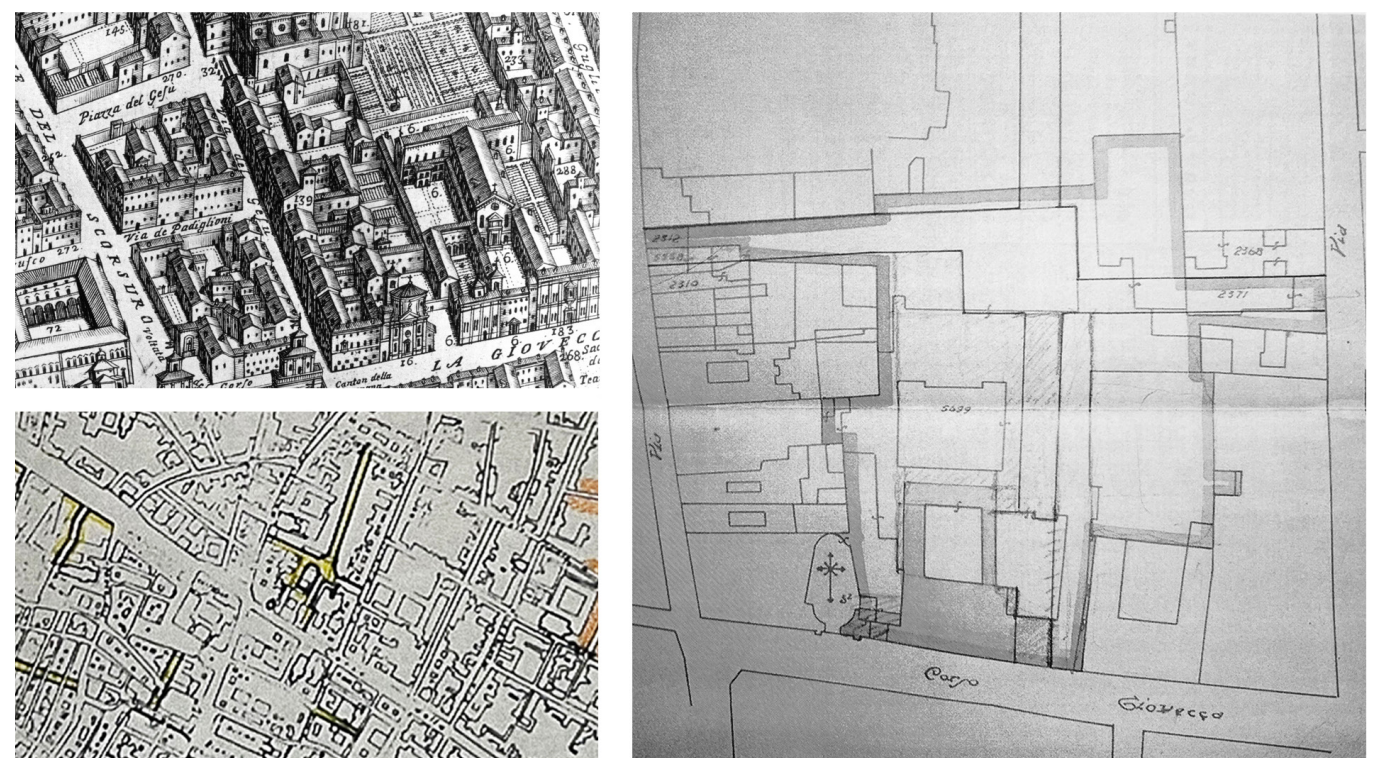
Fig. 2. Prospettiva Dopolavoro Ferroviario. Archivio Storico Comunale di Ferrara, Repertorio XX Secolo, Sezion Cartog secolo, Pubblica Istruzione, $2 \mathrm{M}$ studio delle proporzioni tra luoghi, pubblici e semipubblici, che ospitano funzioni diverse. Un atteggiamento di mimesi nel rapporto con le preesistenze quattrocentesche, da un lato, e di modernità, dall'altro, guidano il progetto di riconfigurazione di un brano di tessuto storico, prossimo al Castello estense e all'addizione Erculea, trasformandolo da antico nosocomio, il primo Arcispedale S. Anna, a quadrivio, sede di edifici pubblici, simbolo della moderna città.
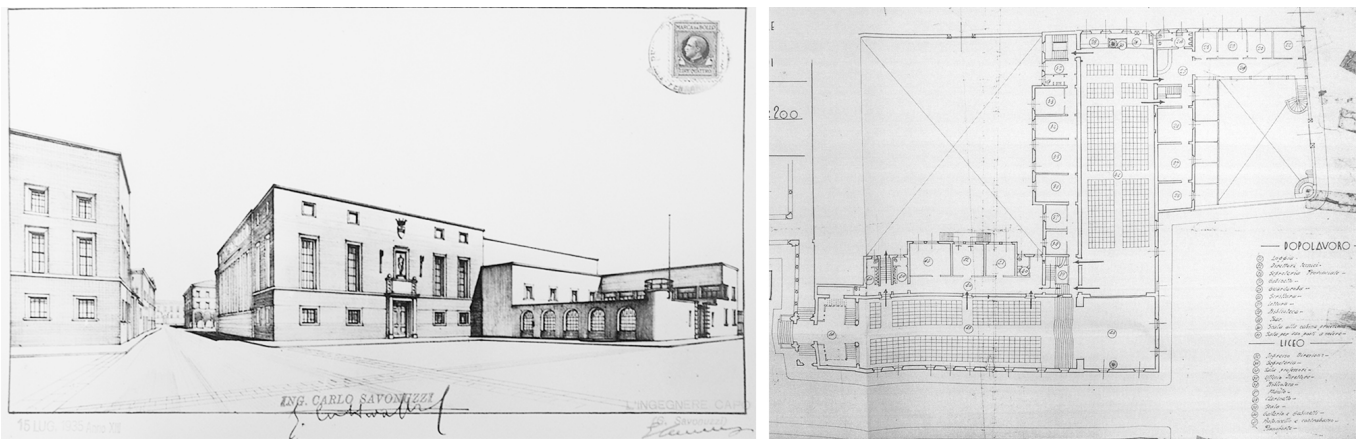

\section{Progetto e disegno della scena urbana}

Nato a Ferrara il 18 agosto 1897, dopo la laurea in ingegneria civile conseguita presso la Regia Scuola di Applicazione di Bologna collabora, a partire dal 1926, insieme all'ingegner Ciro Contini alla redazione della seconda variante del Piano Regolatore Generale della città di Ferrara [Scardino 1987]. Tale è l'occasione dalla quale prende avvio una riflessione sulla forma della città moderna che culminerà, dopo numerosi interventi di restauro e nuova progettazione architettonica e urbana all'interno del tessuto storico e non solo, nel progetto di un nuovo quartiere urbano, in luogo del tre-quattrocentesco Arcispedale di Sant'Anna, ormai inadeguato a ospitare le funzioni di ricovero [Fabbri 2008]. Nel I93I a seguito del definitivo trasferimento, avvenuto nel 1927, dell'istituto sanitario nella sede novecentesca di Corso Giovecca, si stabilisce di intervenire definitivamente all'interno di un'area la cui con-
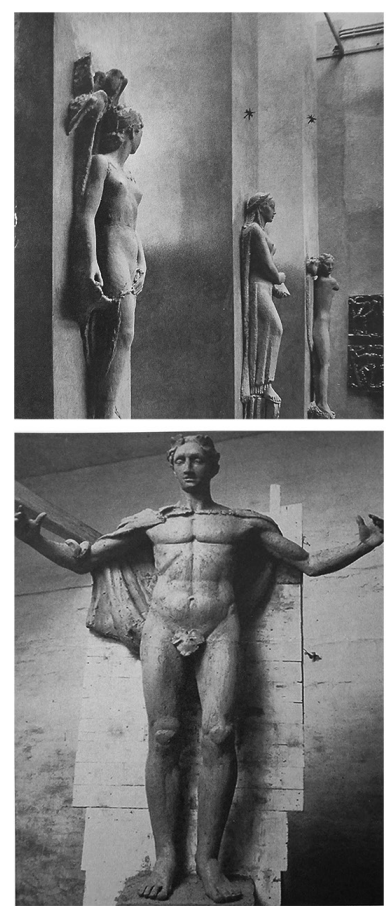
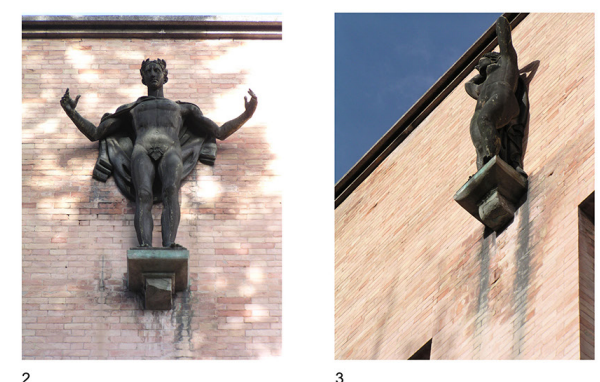

3
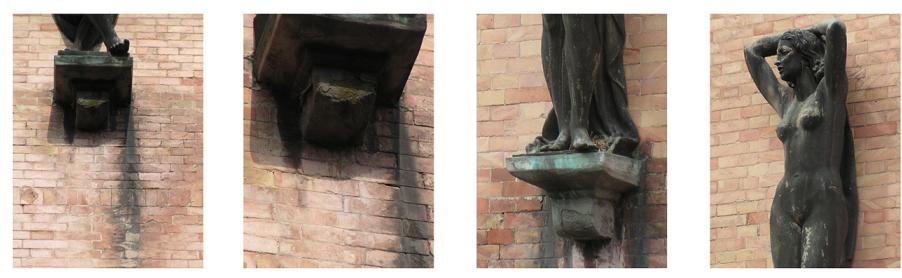
figurazione, nel corso di trasformazioni secolari, aveva saturato l'ampio lotto con fabbricati eterogeni per dimensione, destinazione d'uso e tipologia [Manzotti 1953]. Restava tuttavia conservata e leggibile la caratteristica configurazione a "T" dell'antico nosocomio, all'interno della quale le sale di degenza principali, l'una per gli uomini, la seconda con funzione di sala principale di degenza, rappresentano il centro del sistema distributivo e spaziale dell'intero complesso [Raco 20I2].

La lettura delle preesistenze rappresenta il punto di partenza della riflessione progettuale dell'ingegner Savonuzzi per la risistemazione dell'intero comparto, che accoglie, al termine dei lavori, la scuola elementare Umberto I, oggi Alda Costa, il Museo di Storia Naturale, il Dopolavoro Ferroviario, oggi Cinema-teatro Boldini e il Liceo Musicale Girolamo Frescobaldi. La forma e l'immagine della nuova Cittadella della Cultura pur indagate dal progettista a partire dalle riflessioni del Piano Contini giungono a una diversa articolazione dello spazio pubblico caratterizzato dal nuovo disegno del fronte urbano lungo il Corso della Giovecca, già canale navigabile, in corrispondenza del nuovo accesso all'area. Una diversa forma e orientamento della piazza centrale, l'incrocio del quadrivio, nell'attento rapporto tra coni e fulcri prospettici indagati dalle vedute di progetto e delle opere realizzate dimostrano l'attenzione al rapporto con l'osservatore e l'intenzione di conferire al progetto realizzato quel carattere di unitarietà, pur mantenendo un rapporto con le preesistenze, e perseguendo, come Savonuzzi stesso riporta nelle relazioni di progetto, "esigenze di dignitoso decoro e onesta economia" coerenti con la realtà di una città modesta, ma dal glorioso passato.

Fig. 4. Lo stato di fatto della sala concerti prima degli interventi di bonifica. Restituzione da rilievo digitale integrato, rilievo topografico e rilievo diretto.
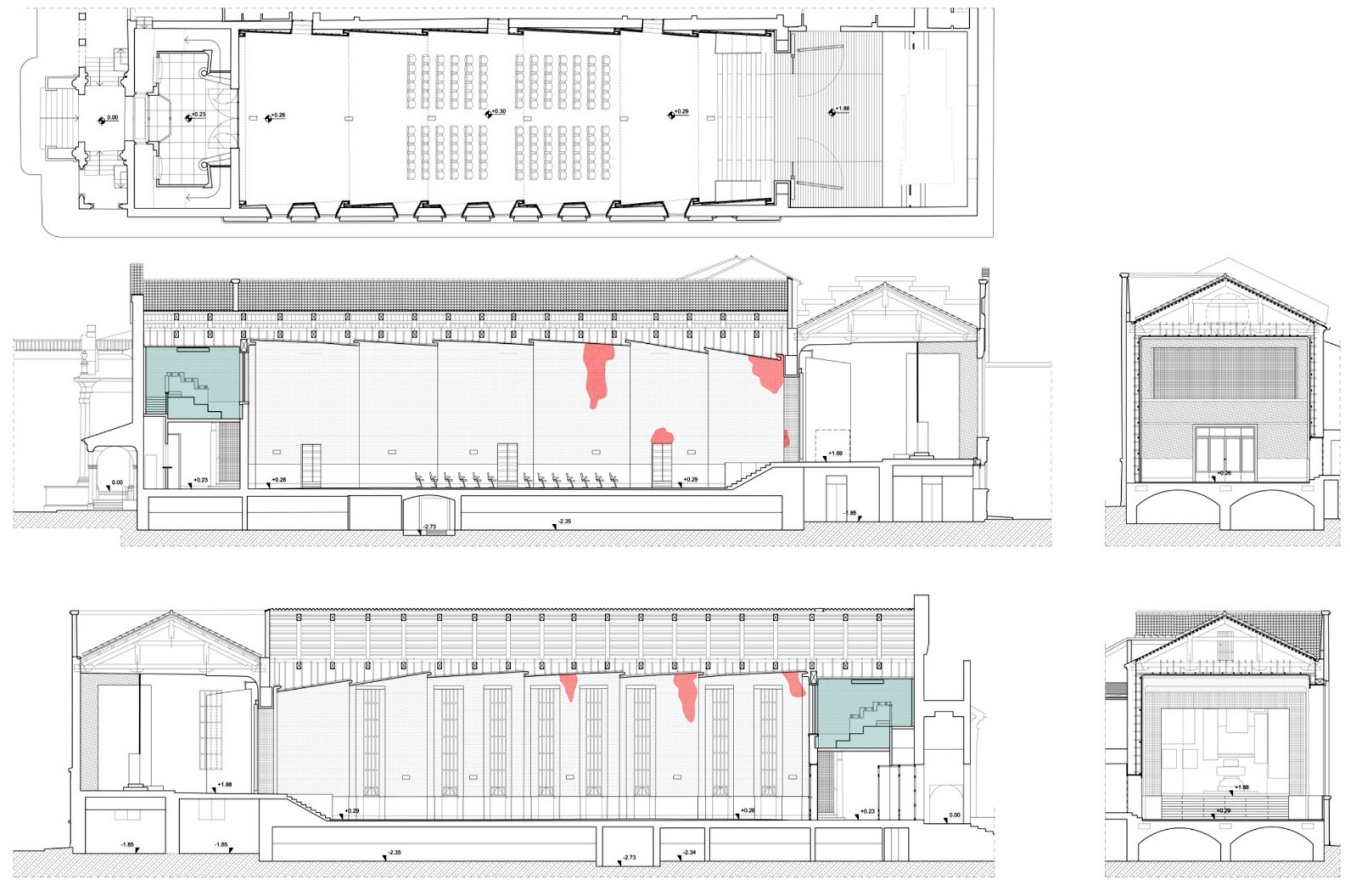

Tra tradizione e innovazione. II progetto della sala concerti

Progetto urbano e progetto architettonico perseguirono l'obiettivo, come emerge dalle numerose relazioni e disegni di progetto, di riconvertire gli edifici storici non procedendo alla totale demolizione e ricostruzione, a eccezione dei fabbricati di servizio, demoliti per ospitare i nuovi assi viari di accesso all'area [Corriere Padano 1932]. Un'intenzione progettuale che è stato possibile verificare nel corso di rilievi e indagini diagnostiche eseguiti in tempi più recenti in occasione del progetto di riapertura della sala concerti e del quale si dirà in seguito. 
Elemento centrale dell'intero progetto la nuova sala concerti annessa al Liceo Musicale, concepita come spazio per la didattica, ma innanzitutto come luogo pubblico in grado di ospitare un pubblico di quattrocento persone e un'orchestra di ottanta elementi. L'ingresso principale della sala è collocato nel volume dell'antico ingresso quattrocentesco sulla Piazzetta Sant'Anna, del quale si conservano integralmente le antiche strutture e il fronte monumentale [Corriere Padano 1931 ]. All'interno dell'atrio è il progetto attento di arredi, materiali e strutture di collegamento verticale, dei quali si conservano dettagli e studi oltre che le relazioni di cantiere, ad anticipare la rilettura che il progettista fa del grande volume dell'antica Prima Sala di degenza, poi platea della nuova sala concerti [Corriere Padano 1937].

Fig. 5. La sala concerti: dettaglio di progetto e immagini storiche (Archivio Storico Comunale di Ferrara, Repertorio XX Secolo Sezione Cartografica, Pubblica Istruzione, $2 \mathrm{M}$ lo stato di fatto prima e dopo gli interventi di bonifica.
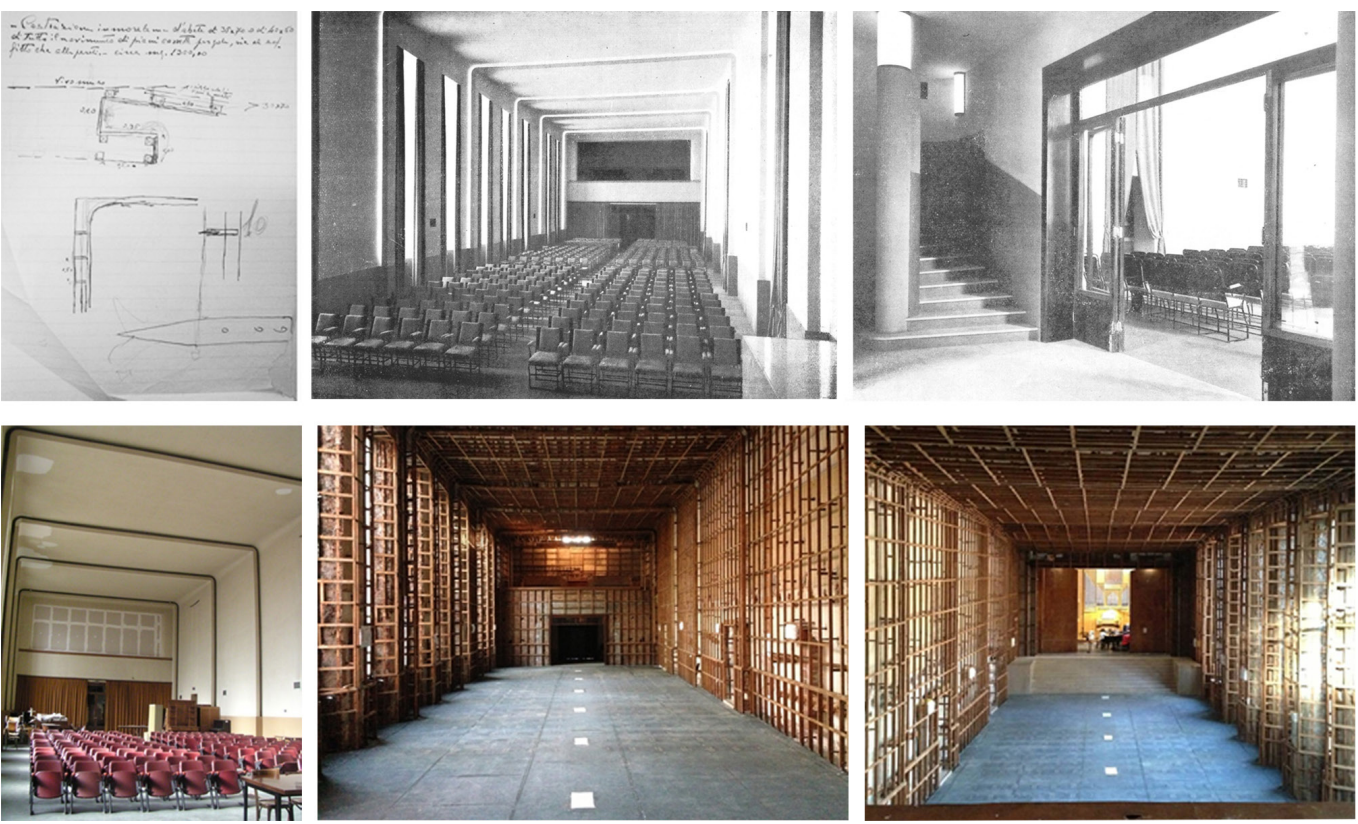

È attraverso lo studio di pochi dettagli e fonti d'archivio prima e l'analisi delle proporzioni dell'opera realizzata poi, attuata grazie a diverse campagne di rilievo tridimensionale, che è possibile rintracciare l'esito delle intenzioni progettuali, pur all'interno di uno spazio fortemente compromesso da interventi di recupero eseguiti nel corso degli anni Ottanta.

La ricerca storica condotta presso l'Archivio Storico Comunale di Ferrara ha permesso di estendere le ricerche all'Istituto Elettrotecnico Nazionale Galileo Ferraris di Torino, al quale l'ingegner Savonuzzi si rivolse per verificare i calcoli sugli intonaci 'acustici', contenenti cioè fibre di amianto, utilizzati come finitura superficiale dell'involucro telescopico in faesite che costituiva, prima dei lavori di bonifica che hanno condotto alla totale demolizione della sala nel 2016, l'architettura e insieme l'arredo dello spazio della platea. Nei documenti e nella corrispondenza intercorsa tra il progettista, l'Istituto Galileo Ferraris e le ditte esecutrici dell'appalto si evince l'intenzione di porre in opera, in relazione dalla distanza dalla sorgente sonora, un intonaco contenente percentuali diverse di amianto al fine di ottenere caratteristiche diversamente assorbenti e tempi di riverbero ottimali per le rappresentazioni orchestrali [Raco 2012].

Le campagne di rilievo tridimensionale integrato condotte unitamente alle campagne diagnostiche dirette, anche in collaborazione con aziende specializzate nel settore, nonché la collaborazione con la scuola di acustica dell'Università degli studi di Ferrara, hanno permesso, come si dirà in seguito, di indagare le geometrie dell'opera realizzata, implementare il quadro conoscitivo delle caratteristiche e prestazioni de materiali in opera e correlare le intenzioni del progetto alle prestazioni dell'opera costruita. 


\section{Rilievo e diagnostica per la comprensione del progetto}

Lo studio prende avvio da una serie di studi e ricerche condotte nell'ambito di una tesi di laurea e successivamente, nel 2006, dalla collaborazione tra l'Università degli Studi di Ferrara, Dipartimento di Architettura e Ingegneria, Comune di Ferrara e Fondazione Cassa di Risparmio di Ferrara, per la definizione di un quadro conoscitivo finalizzato al restauro e alla riapertura della sala concerti, chiusa la pubblico dal 1999 a seguito dell'entrata in vigore della Legge 257 del 27 marzo 1992 che vieta l'estrazione, commercializzazione, lavorazione dei prodotti in cemento amianto e successive disposizioni attuative finalizzate alla gestione dei rischi di luoghi contaminati. Quadro conoscitivo che non impedisce, tuttavia, la demolizione della sala concerti, nel corso del 20 I5, al fine della completa bonifica del luogo.

L'occasione della collaborazione interdisciplinare costituisce al contempo l'opportunità di proseguire un percorso di conoscenza e approfondimento dei metodi e delle innovazioni del fare architettura che caratterizzano quella particolare stagione, nel periodo tra le due guerre, contrassegnata da una spinta all'industrializzazione della filiera. Percorso di ricerca che conduce oggi a indagare con la medesima attenzione la diffusione dei fenomeni di digitalizzazione, nel rapporto tra rappresentazione, progetto e gestione organizzazione della filiera.
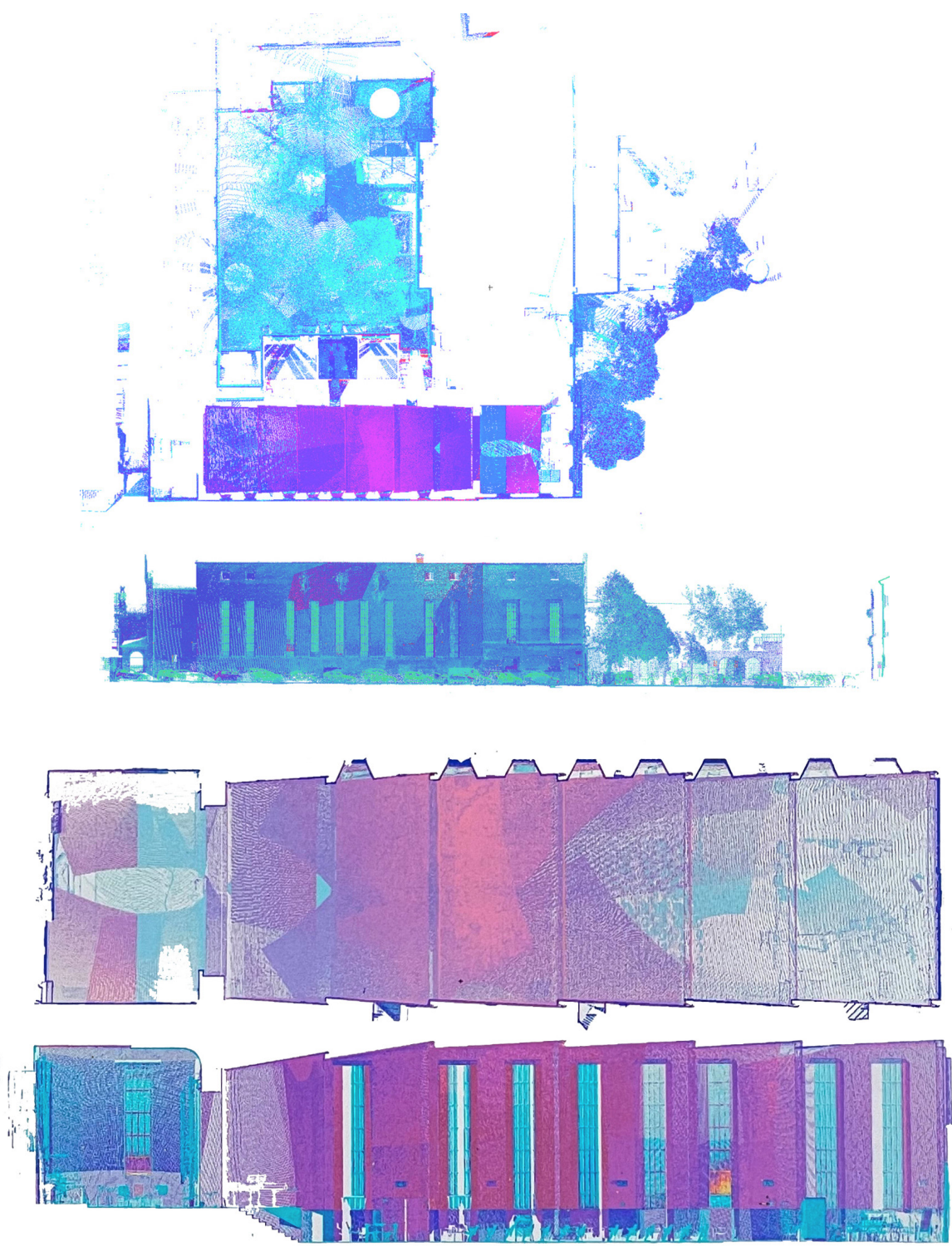
II progetto di Carlo Savonuzzi, che si esprime da un lato nell'attenta rappresentazione della scena urbana, indaga, attraverso un salto dalla scala urbana alla scala di dettaglio, particolari costruttivi, scelte tecnologiche innovative, quali la 'produzione in serie' della pietra artificiale, in un rapporto costante con le imprese esecutrici e le scienze applicate più mature.

È dal disegno di dettaglio, dalle notazioni a margine, dagli abachi che è possibile prefigurare la valenza e il rapporto del singolo particolare in relazione al sistema edificio [De Simone 1980]. II rilievo e la diagnostica integrati divengono pertanto il mezzo per ricucire il racconto, comprendere e verificare il passaggio dall'idea al progetto, all'architettura costruita, attraverso le molteplici finalità che il progetto esprime: rapporto con l'antico; rapporto con il contemporaneo; innovazione e sperimentazione; rapporto con l'industria e la produzione di materiali e componenti.

Analogamente si inseriscono studi successivi condotti in collaborazione con imprese leder nella produzione di materiali e soluzioni per il mercato delle costruzioni, ancorché finalizzati alla conservazione di architetture minori, ma testimonianza di un fare progettuale la cui memoria è oggi affidata unicamente, poiché la materia è andata perduta, a visualizzazioni e ricostruzioni digitali.
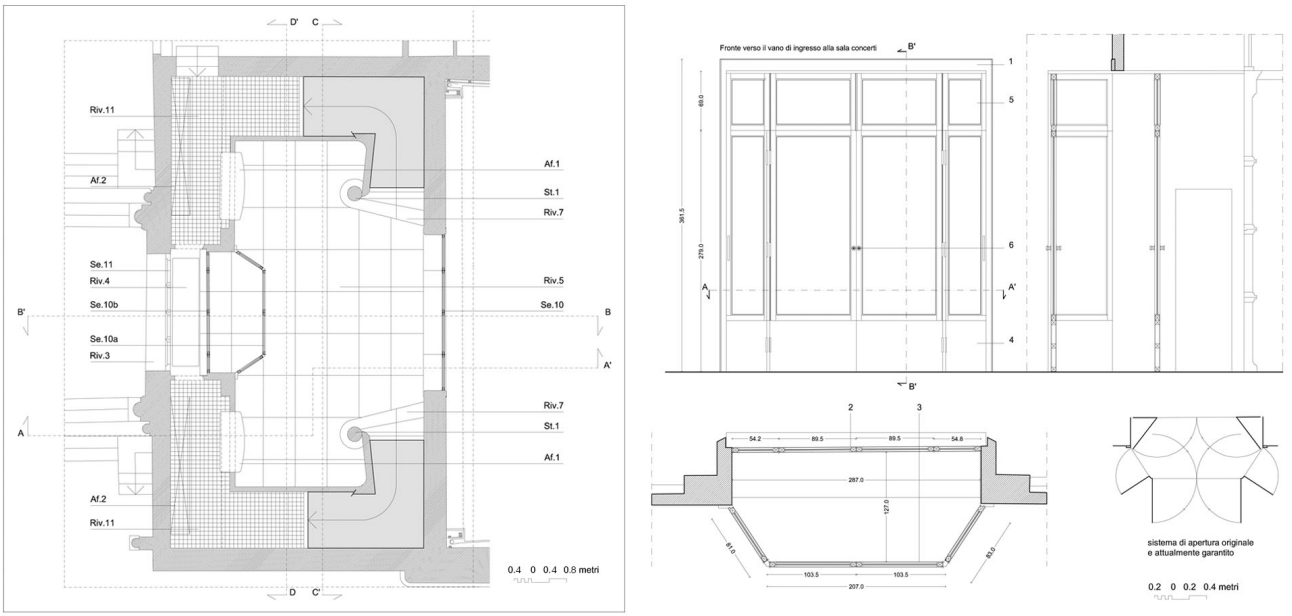

\section{Conclusioni}

La ricerca intorno al rapporto tra rappresentazione e progetto di architettura, al progetto come messaggio e linguaggio, nell'ambito specifico del passaggio da un processo progettuale di tipo artigianale a uno di tipo industriale, individua nel contesto attuale, caratterizzato dalla diffusione di nuovi strumenti della rappresentazione, un rinnovato momento di riflessione. I nuovi criteri di relazione, classificazione, definizione di 'famiglie', di componenti ed elementi, sembrano nuovamente incidere sulla definizione di principi di relazione e interdipendenza [Gregotti 20I4] strettamente correlati alle diverse scale che il progetto di architettura impone. L'autonomia della rappresentazione come atto di conoscenza, innanzitutto, prima ancora che come azione progettuale che classifica, pone in relazione, propone e trasferisce istruzioni [De Simone 1980] sembra essere via via messa in discussione nel passaggio a successivi livelli di industrializzazione ai quali si assiste, in modo sempre più rapido, dal XX secolo a oggi. Un tema che coinvolge non solo la sfera della ricerca, ma forse ancor più quella della didattica in un momento in cui la necessità, e insieme richiesta, di trasferire strumenti 'utili' alla professione, abilità e competenze, appare talvolta a discapito di quella pratica, quotidiana e paziente, che è l'atto del rappresentare per esplorare i molteplici significati e sistemi di relazione frutto del rapporto tra percezione, ideazione e definizione delle qualità formali, materiali e costruttive del progetto concepito. 
Fig. 9. Indagini

diagnostiche condotte su campioni d'intonaco in cemento-amianto. Sezion lucide trattate con rivestimento incapsulante (in collaborazione con Mapei Spa).
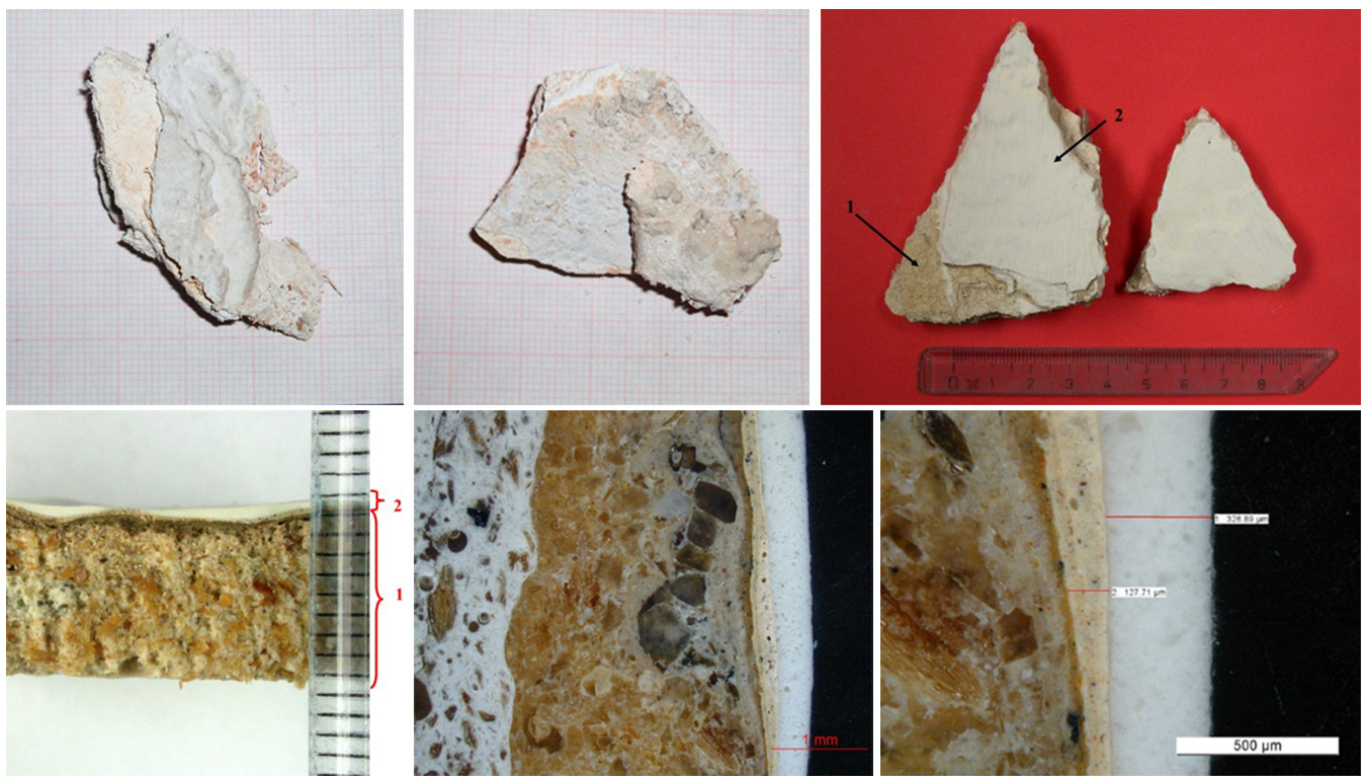

Riferimenti bibliografici

Corriere Padano, Le trasformazioni del Palazzo Sant'Anna, Fondo Archivio Biblioteca Comunale Ariostea, I3 novembre I93।. Corriere Padano, Le demolizioni nel vecchio ospedale Sant'Anna, Fondo Archivio Biblioteca Comunale Ariostea, I6 marzo 1932. Corriere Padano, La sistemazione della sala concerti, Fondo Archivio Biblioteca Comunale Ariostea, 17 settembre 1937.

De Saussure F. (2009). Corso di linguistica generale. Roma-Bari: Laterza.

De Simone M. (1980a). I| progetto come significante. In M. De Simone. Rappresentazione, impegno, metafora, pp. I03-|31. Palermo: Celup.

De Simone M. (1980b). II progetto come significato. In M. De Simone. Rappresentazione, impegno, metafora, pp. I32-I39. Palermo: Celup.

Fabbri R. Raco F (2008). Conservare i moderni restauri. Nuovi indirizzi di ricerca per la conservazione dei materiali in cemento-amianto. In G. Biscontin, G. Driussi (a cura di). Restaurare i restauri. Metodi, compatibilità, Cantieri, Scienza e Beni Culturali. Atti del XXIV Convegno di Studi. Bressanone 24 -27 giugno 2008, pp. 7I-80. Bressanone: Arcadia Ricerche.

Gaiani M. Rappresentare il progetto. In Enciclopedia Treccani: <https://www.treccani.it/enciclopedia/rappresentare-il-progetto_\%28XXI-Secolo\%29/> (consultato il 20 maggio 2021)

Gregotti V. (20|4). I/ territorio dell'architettura. Milano: Feltrinelli.

Manzott, M. (1953). Cinque secoli di storia dell'arcispedale S. Anna di Ferrara. In L'arcispedale S. Anna di Ferrara, vol. 6, f. I, p. 33.

Raco F. (2012). Elementi conoscitivi per la storia dell'area e del complesso architettonico. In Ricomposizioni di uno spazio per la musica, pp. 17-29. Macerata: Quodlibet.

Scardino L. (1987). Ciro Contini ingegnere e urbanista. Ferrara: Liberty House.

\section{Autore}

Fabiana Raco, Università degli Studi di Ferrara, rcafbn@unife.it

Per citare questo capitolo: Raco Fabiana (202I). Le intenzioni di progetto. Disegno, rilievo e documentazione di luoghi della rappresentazione/The purpose of design. Drawing, survey and documentation of the places of performance. In In Arena A., Arena M., Mediati D., Raffa P. (a cura di). Connettere. Un disegno per annodare e tessere. Linguaggi Distanze Tecnologie. Atti del $42^{\circ}$ Convegno Internazionale dei Docenti delle Discipline della Rappresentazione/Connecting. Drawing for weaving relationship. Languages Distances Technologies. Proceedings of the $42^{\text {th }}$ International Conference of Representation Disciplines Teachers. Milano: FrancoAngeli, I047-1062. 


\title{
The Purpose of Design. Drawing, Survey and Documentation of the Places of Performance
}

\author{
Fabiana Raco
}

Abstract

Architecture and message. "If we consider that the notion of message implies that of language, in our case the project communicates through a language" [De Simone 1980]. As a language, architecture requires the faculty to select and relate information, thoughts, feelings, and to define the types of tools and forms, techniques, the signifier, in order to effectively transfer the intentions, meaning, of the project. Language implies criteria, methods and plurality of purposes; technical, scientific, poetic, literary. Therefore, the representation of a project becomes, through the means available to it in a given historical period, the object of investigation, as well as the survey, diagnostics techniques and advanced visualization tools to trace, and maintain memory, of the meanings underlying the architectural project. Architecture and message-language in the transition from craft to industrial know-how, as occurs, for example, in the twentieth century between the two World Wars, is a line of research that identifies in the case study of the Citadel of Culture in Ferrara an interesting occasion of reflection on the relationship between representation and design, in the context of a minor historical city center.

Keywords

project, language, drawing, survey, representation.

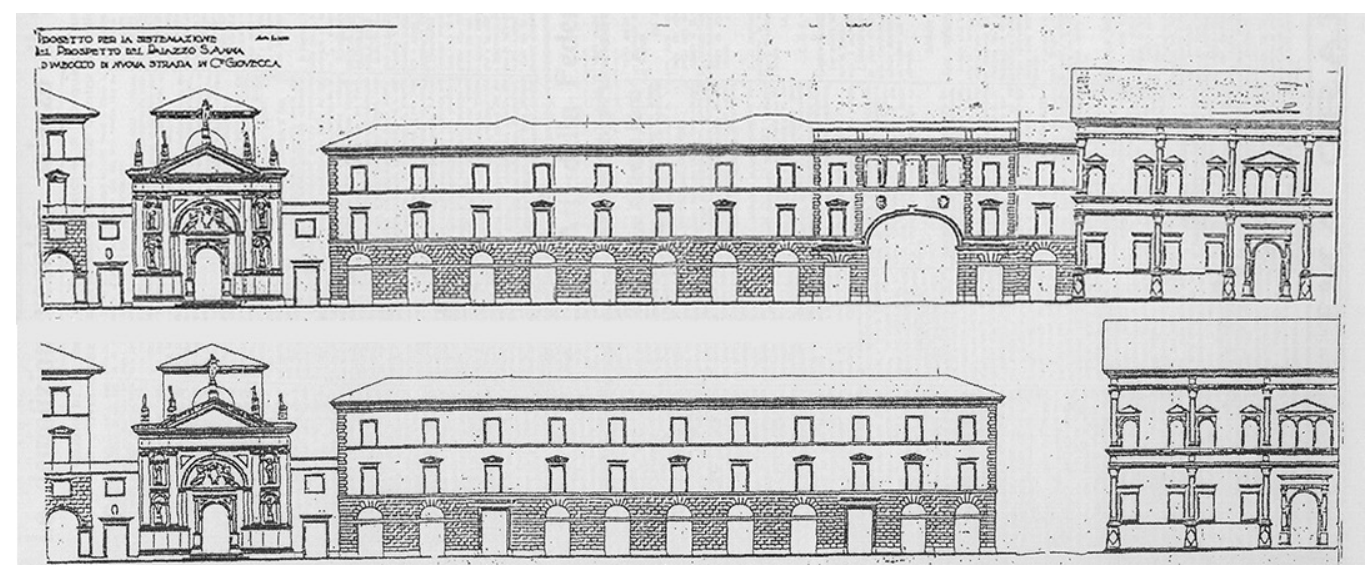




\begin{abstract}
"I like in architecture things as a whole. $[\ldots]$ This is what I mean in few words: our rationalist circles deny, in truth only theoretically, the fundamental, human function of beauty, that is, the beneficial and invigorating action that harmony has on us." [Le Corbusier 194I].
\end{abstract}

The project of the engineer Carlo Savonuzzi for the new Citadel of Culture in the city of Ferrara, realized between 1931 and 1939, is part of the cultural area of the Modern Movement, which while opening a season of criticism with respect to previous methods of representation of the project, and not only, recovers, in analogy to some masters such as Khan and Alto, the central role of some figurative expressions, such as perspective for example, to describe the relationship between context and observer [De Simone 1980].

Definitely, with reference to the architectural project, as well as the design of industrial products, the objects of observation are both the means of representation, the signifier [De Saussure 2009], as well as the aim, the meaning [De Saussure 2009], by virtue of the recursive action that binds them [Gaiani 20 I0], in order to identify the relation between the autonomy of the act of representation and the building as is over the time.

The relation among the observer, the user, and the architecture leads in the same way the technological and detailed project of the new district, which is based, in the specific case of the project under consideration, on the application of 'modern acoustic science' and the experimental use of innovative materials, such as asbestos cement, for the project of the concert hall of the new Liceo Musicale Girolamo Frescobaldi. The study of the relation between the project and the message-language investigates, through the analysis of the project drawings before the architecture, the relation among the idea, the structure, the form and the technological and material choices, in the context of the specific typology of a place of performance, such as the concert hall and not only. Showing a scene to the observer, representing, is the fundamental aim of Carlo Savonuzzi's project. The relation between the scenic space and the spaces of the observer, the stalls and the gallery, is defined as much by functional needs as by the architectural composition and the nexsus with the pre-existing ancient structures. Generatrix of the urban plant pursues the same compositional principles, while the juxtaposition of ancient modern structures defines the main fronts, allowing at the same time the reading of the ancient buildings and the unity of the modern urban scene. A urban scale project, as well as architectural and detailed scales, which is expressed in the design of materials and technologies, both contemporary and traditional, as well as in the study of proportions between places, public and semi-public, which host different functions.

Fig. I.A. Bolzoni, Plan and elevation of the city of Ferra, 1747 (detail). Contini, Ciro, Piano Regolatore Generale e d'Ampliamento della città e dei sobborgh di Ferrara, 19|3-26, Archivio Storico Comunale di Ferrara, Repertorio XX secolo Sezione Cartografica, Piani Generali, cart. IH. Savonuzzi, Carlo, sketch for the transformation of the area of the former Sant'Ann Hospit Sant'Anna Hospital, project realized, 1932 Savonuzzi Archive,
Department of Architecture, University of Ferrara.
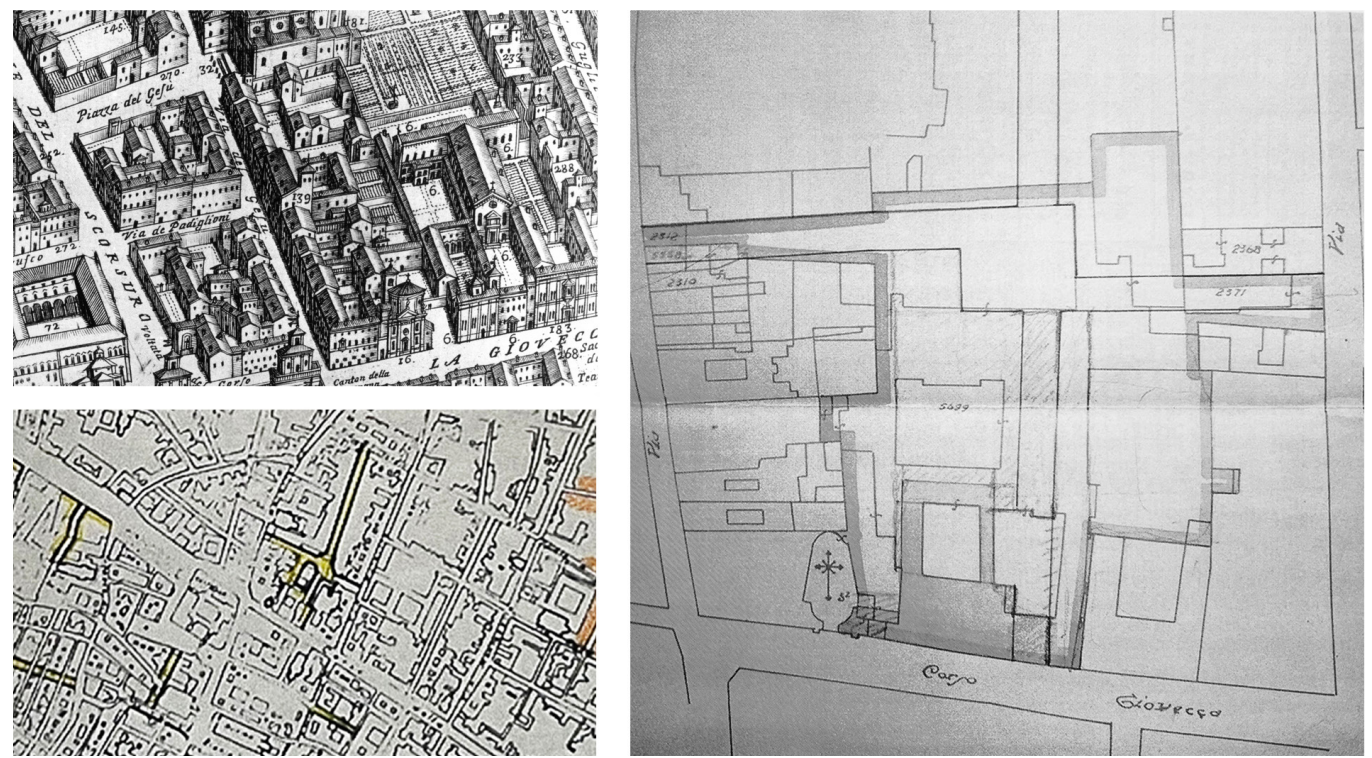
Fig. 2. Sketch for the Liceo Musicale e Dopolavoro Ferroviario. Historical Archive of Ferrara, Repertory XX Century, Cartographic Section Public Education, 2M.
An attitude of mimesis in the relation with the pre-existing fourteenth -century buildings, on the one hand, and of modernity, on the other, guide the project of reconfiguration of a piece of historical fabric, close to the Este Castle and to the Erculean Addition, transforming it from an ancient hospital, the first Arcispedale Sant'Anna, to a crossroads, seat of public buildings, symbol of the modern city.
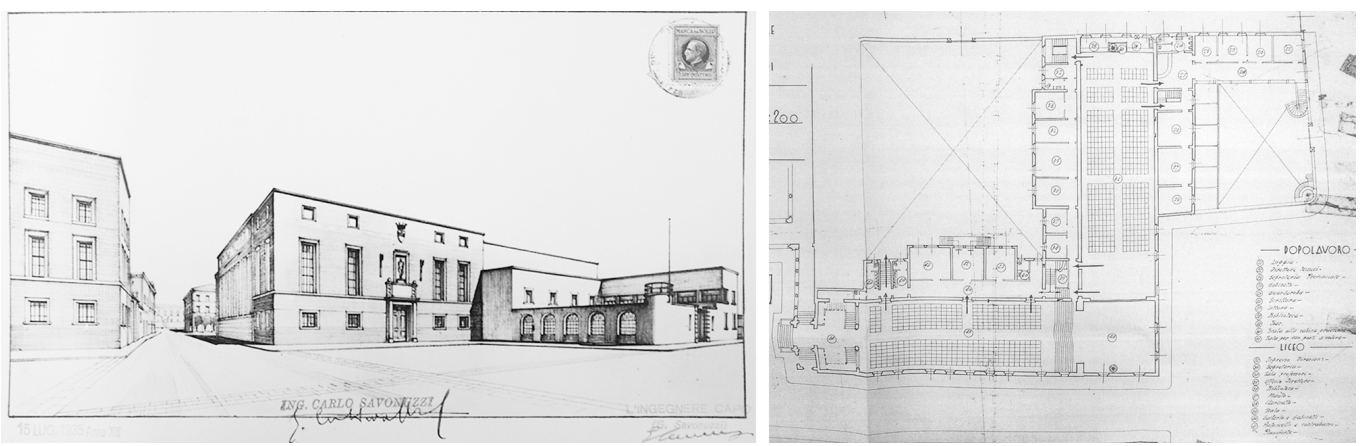

\section{Project and design of the urban scene}

Born in Ferrara on August 18th, 1897, after graduating in civil engineering at the Royal School of Application in Bologna collaborates, since 1926, along with engineer Ciro Contini to the drafting of the second variant of the General Regulatory Plan of the city of Ferrara [Scardino 1987]. This is the occasion from which begins a reflection on the shape of the modern city that will culminate, after numerous interventions of restoration and new architectural and urban design within the historical city center and beyond, in the project of a new urban district, in place of the fourteenth century Arcispedale di Sant'Anna, now inadequate to accommodate the functions of shelter [Fabbri 2008]. In 1931, after the final transfer, which took place in 1927, of the health institute in the twentieth-century site of Corso
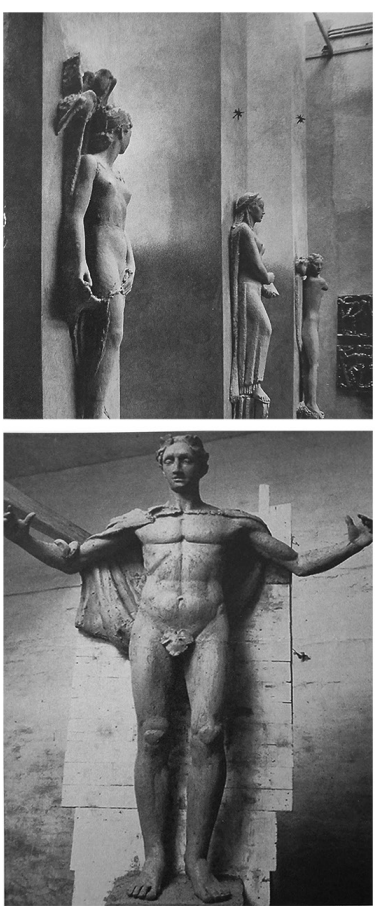
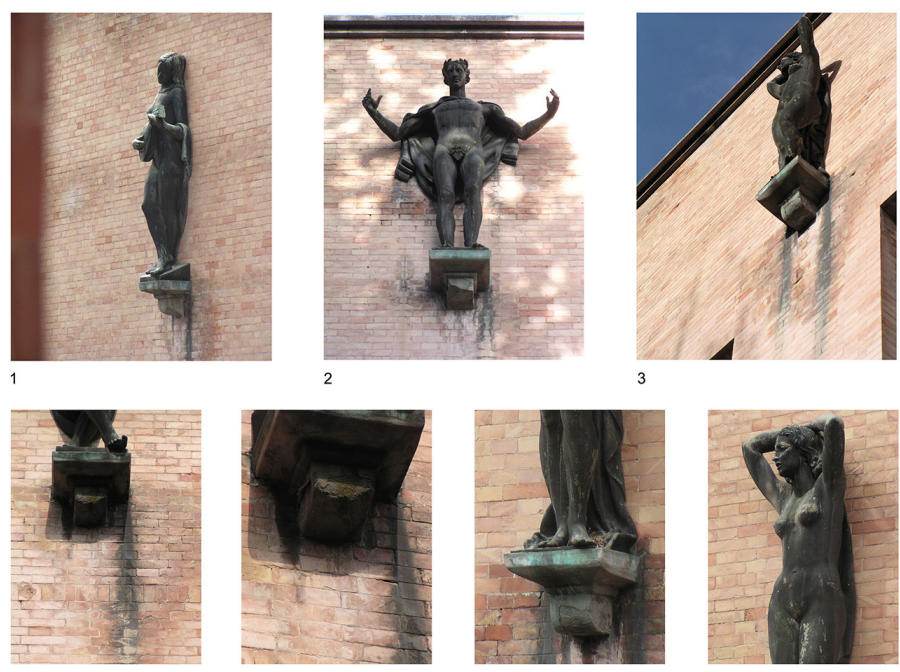
Giovecca, it was decided to intervene permanently in an area whose configuration, during centuries of transformation, had saturated the large lot with buildings of heterogeneous size, use and typology [Manzotti 1953]. However, the characteristic "T" configuration of the ancient hospital remained preserved and legible, within which the main hospital rooms, one for men, the second with the function of main hall of hospitalization, represent the center of the distribution and spatial system of the entire complex [Raco 20 I2].

The understanding of the pre-existing buildings represents the starting point of Savonuzzi's design reflection for the rearrangement of the entire area, which houses, at the end of the work, the elementary school Umberto I, today Alda Costa, the Museum of Natural History, the Dopolavoro Ferroviario, today Cinema-Theater Boldini and the Liceo Musicale Girolamo Frescobaldi. The shape and the image of the new Citadel of Culture, although investigated by the designer starting from the reflections of the Contini Plan, define a variety of public spaces characterized by the new design of the urban front along Corso della Giovecca, formerly a navigable canal, in correspondence of the new access to the area. A different shape and orientation of the central square, the crossing of the crossroads, in the careful relation between cones and perspective fulcrums investigated by the views of the project and of the realized works show the attention to the point of view of the observer and the intention to realize a unity, while maintaining a relation with the pre-existences, and pursuing, as Savonuzzi himself reports in the project reports, "needs of dignified decorum and honest economy" consistent with the reality of a modest city, but with a glorious past.
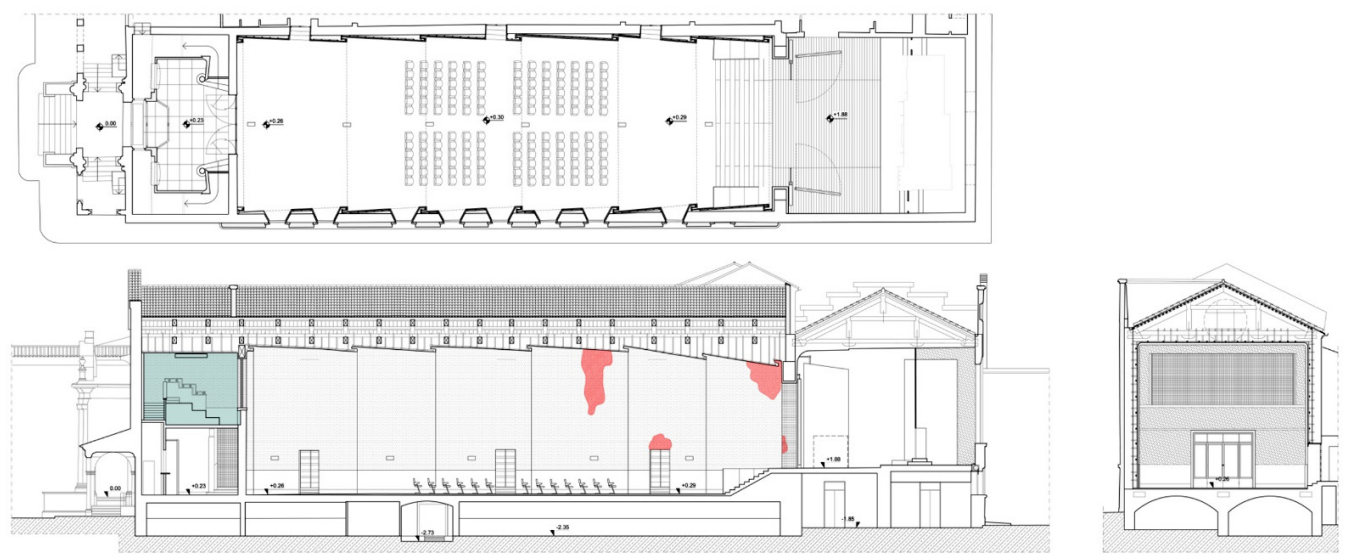

Fig. 4. The state of art of the concert hall before the restoration works. Representation from integrated digital survey, integrated digital survey,
topographic survey and direct survey.
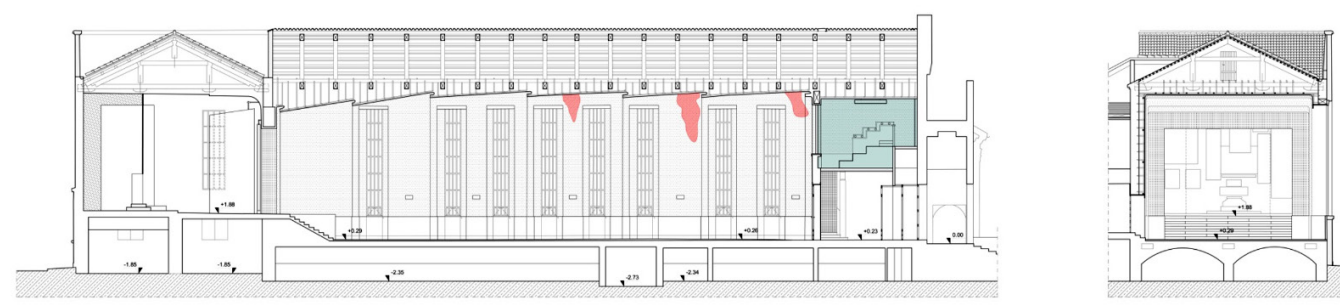

\section{Between tradition and innovation. The project of the concert hall}

The urban and architectural project aimes at, as emerges from the numerous reports and drawings, reconverting the historic buildings without proceeding to total demolition and reconstruction, with the exception of the service buildings, demolished to accommodate the new access roads to the area [Corriere Padano 1932]. A design intention that it was possible to verify during surveys and diagnostic investigations carried out in more recent times on the occasion of the project for the reopening of the concert hall, which will be discussed later. 
Central element of the entire project is the new concert hall enclosed to the Liceo Musicale, conceived as a space for teaching, but first and foremost as a public place able to accommodate an audience of four hundred people and an orchestra of eighty elements. The main entrance of the hall is located in the volume of the ancient fourteenth-century entrance on Piazzetta Sant'Anna, of which the ancient structures and the monumental front are fully preserved [Corriere Padano 193I]. Inside the atrium, it is the careful project of furnishings, materials and vertical connection structures, of which details and studies as well as site reports are preserved, to anticipate the reinterpretation that the designer makes of the great volume of the ancient First Hospital Hall, then stalls of the new concert hall [Corriere Padano 1937].

Fig. 5. The concert hall: project details and historical images (Historical Archive of Ferrara, Repertory XX Century, Cartographic Section, Public Education, $2 \mathrm{M}$; the state of the art before and after the restauration interventions.
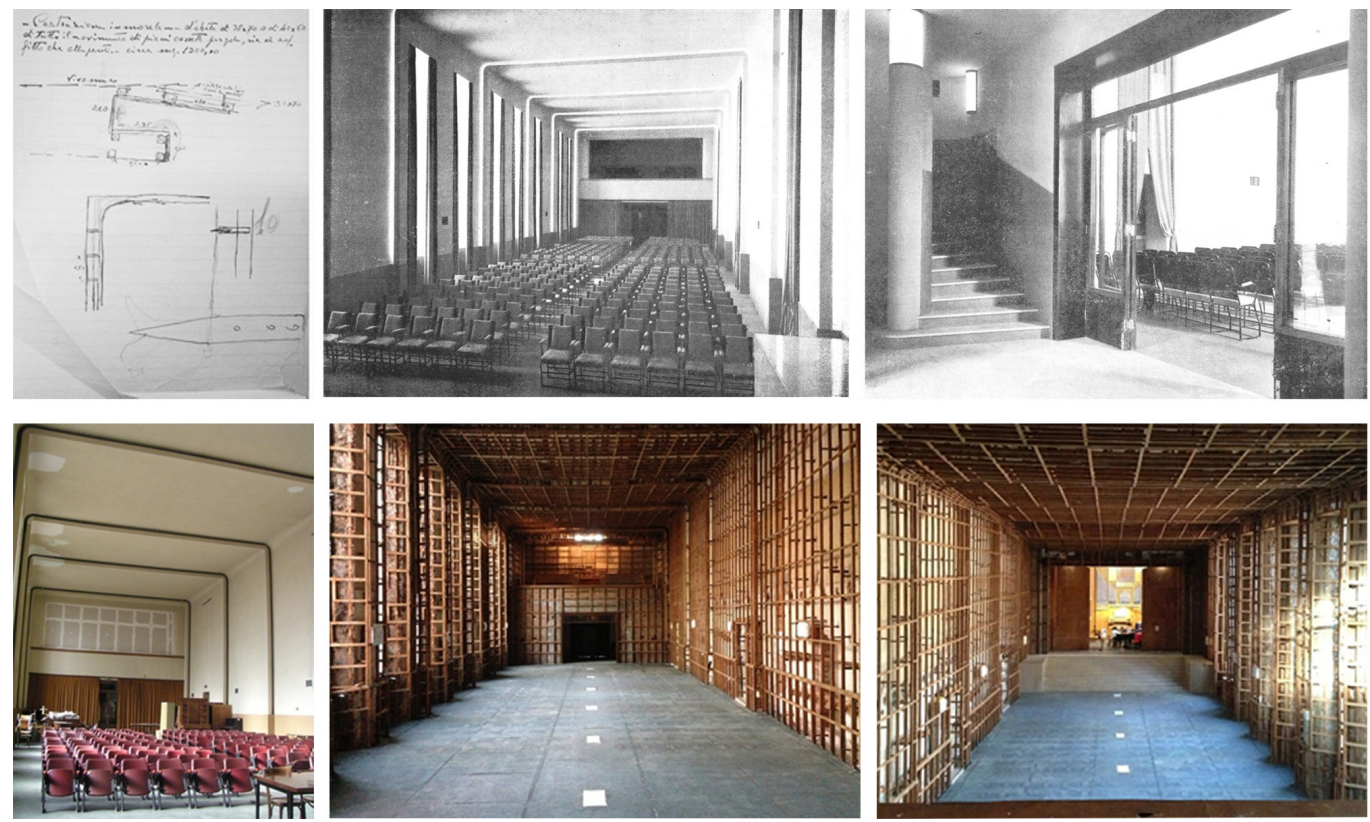

Definitely, the study of few details and archival sources first and then the analysis of the proportions of the completed work, carried out thanks to several three-dimensional survey campaigns, traces the outcome of the design porpuses, even within a space that was heavily compromised by the restoration work carried out during the 1980s.

The historical research conducted at the Municipal Historical Archive of Ferrara has allowed to extend the research to the National Electrotechnical Institute Galileo Ferraris of Turin, to which the engineer Savonuzzi turned to verify the calculations on the 'acoustic' plasters, containing asbestos fibers, used as a surface finish of the telescopic faesite shell, which constituted, before the reclamation works that led to the total demolition of the hall in 2016, the architecture as wella as the furniture of the space. Moreover, the documents and in the correspondences between the designer, the Galileo Ferraris Institute and the companies executing the contract explain the intention to put in place, in relation to the distance from the sound source, a plaster containing different percentages of asbestos in order to obtain different absorbent characteristics and optimal reverberation times for orchestral performances [Raco 20I2].

The integrated three-dimensional survey campaigns carried out together with direct diagnostic campaigns, also in collaboration with companies specialized in the field, as well as the collaboration with the school of acoustics of the University of Ferrara, have allowed, as will be said later, to investigate the geometry of the architecture, to implement the cognitive framework of the characteristics and performance of materials in place and correlate the porpuses of the project to the performance of the built project. 


\section{Understanding the poject though survey and diagnostics analysis}

The study starts from a series of studies and researches carried out as part of a degree thesis and then, in 2006, from the collaboration between the University of Ferrara, Department of Architecture and Engineering, Municipality of Ferrara and Fondazione Cassa di Risparmio di Ferrara, for the definition of a knowledge framework aimed at the restoration and reopening of the concert hall, closed to the public since 1999 following the entry in force of Law 257 of the 27th March 1992 prohibiting the extraction, marketing, processing of asbestos cement products and subsequent implementation provisions aimed at managing the risks of contaminated sites. The knowledge framework does not prevent, however, the demolition of the concert hall, during 2015, in order to complete reuse of the place. The occasion of the interdisciplinary collaboration constitutes at the same time the opportunity to continue a path of knowledge and deepening of the methods and innovations of making architecture that characterize a particular season, in the period between the two World Wars, marked by a push to the industrialization of the construction sector. Research path that leads today to investigate, with the same attention, the spread of the phenomena of digitalization, in the relationbetween representation, design and management of the supply chain.
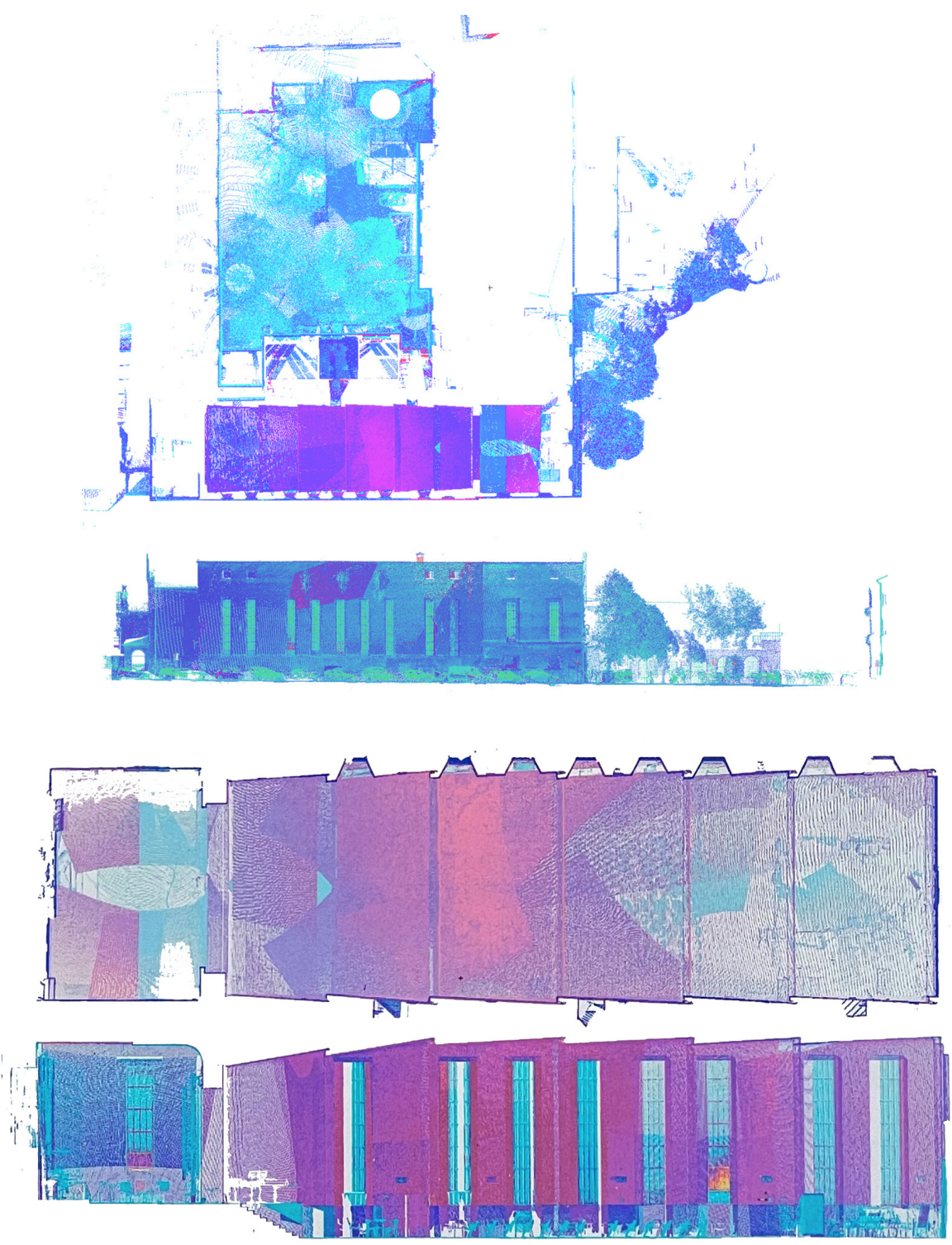
Carlo Savonuzzi's project, which expresses itself on the one hand in the careful representation of the urban scene, investigates, through a leap from the urban scale to the scale of detail, construction details, innovative technological choices, such as the 'mass production' of artificial stone, working with the contractors and the most innovative applied sciences. It is from the detailed drawing, from the notations in the margin, from the abacuses that it is possible to prefigure the value of a single detail in relation to the building system it self [De Simone 1980]. Therefore, the survey and the integrated diagnostics techniques become the means to stitch the story, to understand and verify the transition from the idea to the project, to the built architecture, through the multiple purposes that the project expresses: relation with the ancient; relation with the contemporary; innovation and experimentation; relation with the industry and the production of materials and components.

Similarly, there are subsequent studies conducted in collaboration with leading companies in the production of materials and solutions for the construction market, even if aimed at the preservation of minor architectures, but evidence of a design process whose memory is now entrusted only to digital visualizations and reconstructions, since the material has been lost.
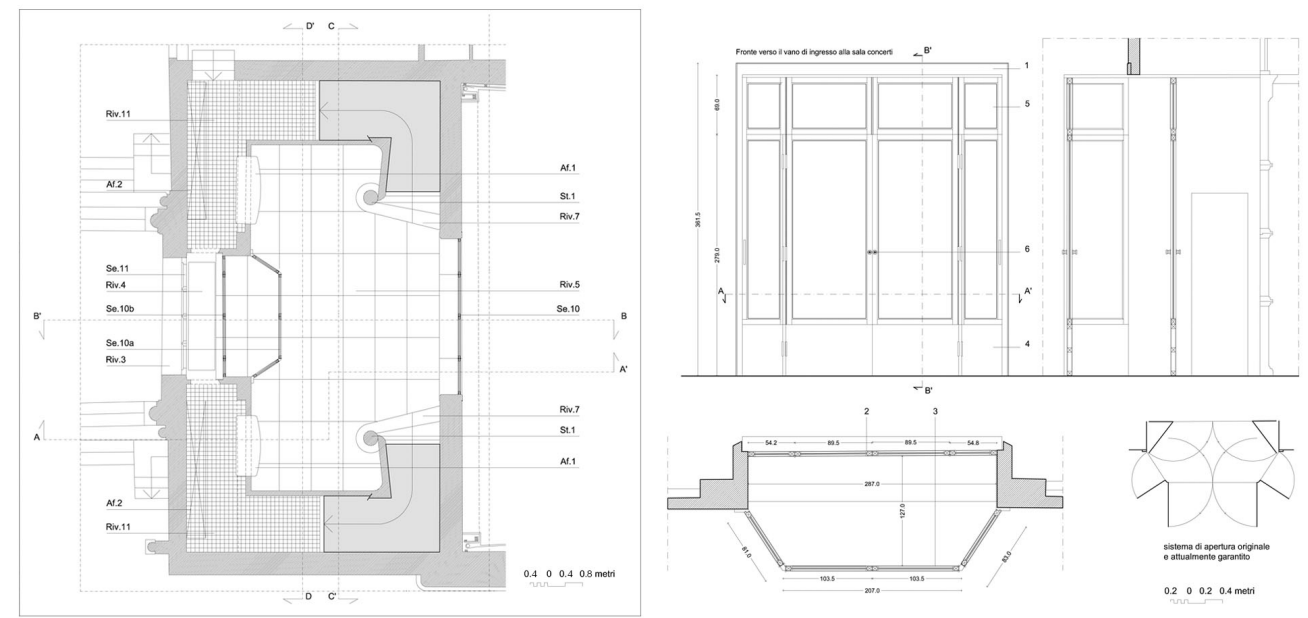

\section{Conclusions}

The research concerning the relation between representation and architectural project, the project as message and language, in the specific context of the transition from handicraft industry to industrial one, identifies in the present context, characterized by the spread of new tools of representation, a renewed moment of reflection. The new criteria of classification, definition of 'families', of components and elements, seem to affect the definition of principles of new interdependence [Gregotti 20I4] closely related to the different scales that the architectural project imposes. The autonomy of representation as an act of knowledge, first of all, even before that as a design action that classifies, relates, proposes and transfers instructions [De Simone 1980] seems to be gradually questioned in the transition to subsequent levels of industrialization, to which we witness, in an increasingly rapid way, from the twentieth century up to now. The subject involves not only the research activities as well as the didactics, which is characterized by the ability to transfer 'useful' professional tools, skills and competencies. Definitely, the scenarioaffects the idea that representing is a way to explore the multiple meanings resulting from the relation between perception, conception and definition of the formal, material and constructive qualities of the project. 
Fig. 9. Diagnostic

investigations conducted on samples of asbestos cement plaster. Glossy sections treated with encapsulating coating (in collaboration with Mape Spa).

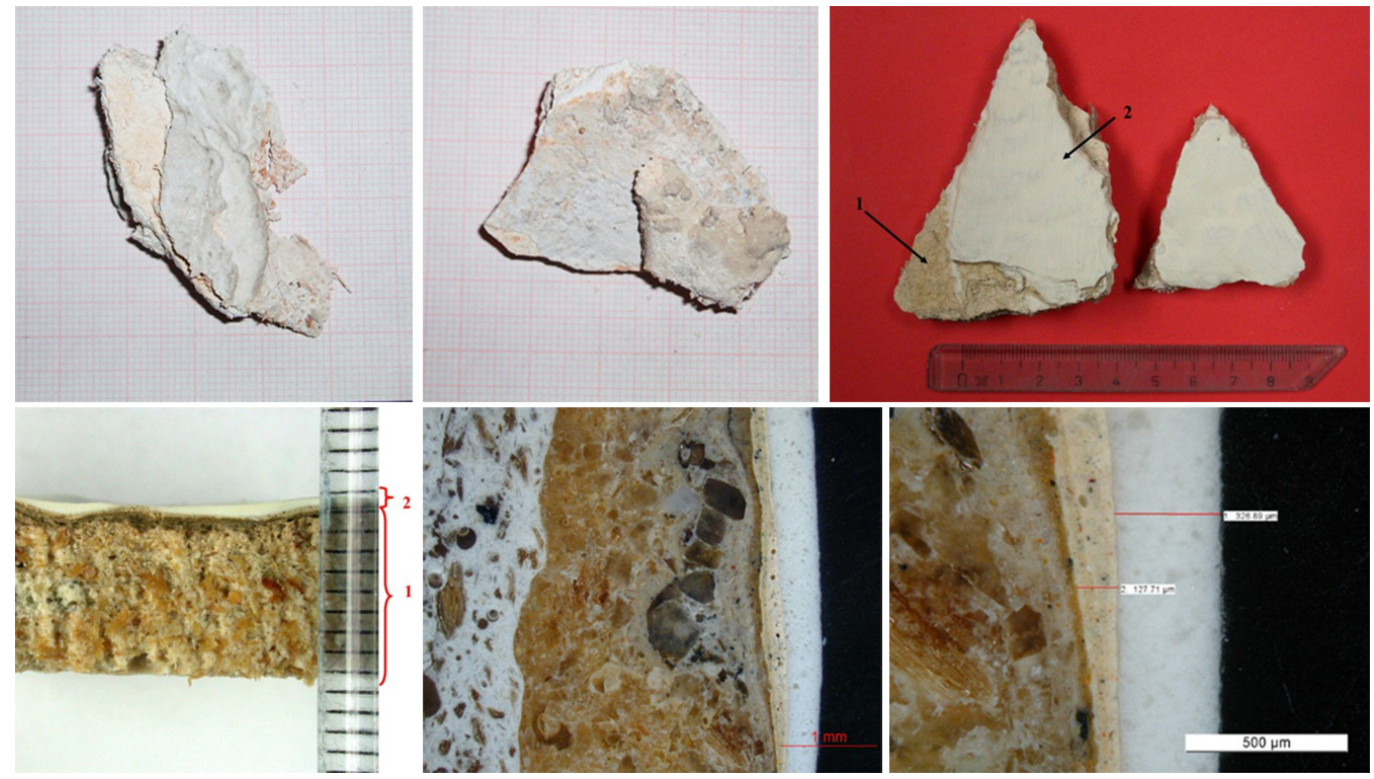

References

Corriere Padano, Le trasformazioni del Palazzo Sant'Anna, Fondo Archivio Biblioteca Comunale Ariostea, 13 novembre 1931. Corriere Padano, Le demolizioni nel vecchio ospedale Sant'Anna, Fondo Archivio Biblioteca Comunale Ariostea, I6 marzo 1932 Corriere Padano, La sistemazione della sala concerti, Fondo Archivio Biblioteca Comunale Ariostea, 17 settembre 1937.

De Saussure F. (2009). Corso di linguistica generale. Roma-Bari: Laterza.

De Simone M. (1980a). || progetto come significante. In M. De Simone. Rappresentazione, impegno, metafora, pp. I03- I31. Palermo: Celup.

De Simone M. (1980b). I| progetto come significato. In M. De Simone. Rappresentazione, impegno, metafora, pp. I32-I39. Palermo: Celup.

Fabbri R. Raco F. (2008). Conservare i moderni restauri. Nuovi indirizzi di ricerca per la conservazione dei materiali in cemento-amianto. In G. Biscontin, G. Driussi (a cura di). Restaurare i restauri. Metodi, compatibilità, Cantieri, Scienza e Beni Culturali. Atti del XXIV Convegno di Studi. Bressanone 24 -27 giugno 2008, pp. 7I-80. Bressanone: Arcadia Ricerche.

Gaiani M. Rappresentare il progetto. In Enciclopedia Treccani: <https://www.treccani.it/enciclopedia/rappresentare-il-progetto_\%28XXI-Secolo\%29/> (accessed 2021, May 20)

Gregotti V. (20|4). I/ territorio dell'architettura. Milano: Feltrinelli.

Manzott, M. (1953). Cinque secoli di storia dell'arcispedale S. Anna di Ferrara. In L'arcispedale S. Anna di Ferrara, vol. 6, f. I, p. 33.

Raco F. (2012). Elementi conoscitivi per la storia dell'area e del complesso architettonico. In Ricomposizioni di uno spazio per la musica, pp. 17-29. Macerata: Quodlibet.

Scardino L. (1987). Ciro Contini ingegnere e urbanista. Ferrara: Liberty House.

\section{Author}

Fabiana Raco, Università degli Studi di Ferrara, rcafbn@unife.it

To cite this chapter. Raco Fabiana (202I). Le intenzioni di progetto. Disegno, rilievo e documentazione di luoghi della rappresentazione/The purpose of design. Drawing, survey and documentation of the places of performance. In In Arena A., Arena M., Mediati D.. Raffa P. (a cura di). Connettere. Un disegno per annodare e tessere Linguaggi Distanze Tecnologie. Atti del $42^{\circ}$ Convegno Internazionale dei Docenti delle Discipline della Rappresentazione/Connecting Drawing for weaving relationship. Languages Distances Technologies. Proceedings of the $42^{\text {th }}$ International Conference of Representation Disciplines Teachers. Milano: FrancoAngeli, 1047-1062 